\title{
Effect of Irrigation Regimes and Staggered Transplanting on Growth and Yield of Summer Rice (Oryza sativa L.) in South Odisha
}

\author{
Sarath Kumar Duvvada*, G.C. Mishra, Sagar Maitra and Rahul Adhikary
}

M.S Swaminathan School of Agriculture, Centurion University of Technology and Management, Paralakhemundi, Odissa, India *Corresponding author: sarathkumarduvvada010@gmail.com (ORCID ID: 0000-0002-5013-5670)

Paper No. 838

Received: $19-12-2019$

Revised: 14-04-2020

Accepted: 27-05-2020

\begin{abstract}
A field experiment was conducted at Agriculture Research Farm, Bagusala, M.S. Swaminathan School of Agriculture, Centurion University of Technology and Management, Paralakhemundi, Odisha during summer season, 2018-19. The soil of experimental field was sandy clay loam in texture, slightly acidic in reaction ( $\mathrm{pH}$ 6.4) low in available nitrogen $(208 \mathrm{~kg} / \mathrm{ha})$ and high in both phosphorus (139 kg/ha) and potassium (390 kg/ha). The field experiment was laid out in split-plot design with three replications and 12 treatments combination. The treatments were comprised of three water regimes assigned in main plot (Continuous ponding, continuous soil saturation and saturation after hair crack) and four transplanting dates in sub plots (Transplanting on $23^{\text {rd }}$ and $31^{\text {st }}$ January, $6^{\text {th }}$ and $13^{\text {th }}$ February). The experimental results revealed that irrigation treatments failed to exhibit significant effect on growth parameters like plant height, tillers/clump, LAI, dry matter production and CGR until the peak crop growing period up to 60 DAT excepting plant height at 60 DAT. Crop growth parameters except LAI were significantly influenced by irrigation regimes at harvest. Irrigation regimes had the remarkably effect of grain yield and WUE but it had no significant effect on straw yield. Irrigation with continuous ponding produced the highest grain yield (4.57 t/ha) which was at par with continuous soil saturation (4.30 t/ha). The WUE was significantly increased with saturation after hair $(49.62 \mathrm{~kg} / \mathrm{ha} / \mathrm{cm})$. Dates of transplanting significantly reflected all the crop growth parameters throughout the crop growing period. Transplanting on $23^{\text {rd }}$ January significantly recorded the highest grain yield ( $4.72 \mathrm{t} / \mathrm{ha})$ and maximum straw yield was obtained in $31^{\text {st }}$ January $(7.99 \mathrm{t} /$ ha) being at par with $23^{\text {rd }}$ January $(7.63 \mathrm{t} / \mathrm{ha})$. Significantly the highest WUE was obtained in transplanting date of $23^{\text {rd }}$ January $(47.09 \mathrm{~kg} / \mathrm{ha} / \mathrm{cm})$.

Highlights

0 The transplanted rice applied with irrigation regime of continuous ponding at the depth of $5 \pm 2 \mathrm{~cm}$ and continuous saturation with the depth of $3 \mathrm{~cm}$ during summer improved the crop growth parameters and enhanced the yield and WUE was positively increased under reduced irrigation of saturation after hair crack with $3 \mathrm{~cm}$ depth.

( Transplanting of rice on $23^{\text {rd }}$ January increased all crop growth parameters, grain yield and WUE over other dates of transplanting.
\end{abstract}

Keywords: Saturation, Leaf area index, Crop growth rate, Water use efficiency

Rice (Oryza sativa L.) is most important staple food crop of South-East Asia and major food source for more than one third of global population (Sarkar et al. 2017). In India, it is cultivated in an average area of 4.16 million ha with the total production of 13.70 million $t$ with an average yield of $3.294 t /$ ha taking the 5years mean from 2012-13 to 2016-17 during summer season (DES, 2018). Irrigated rice requires effective water management during the entire crop cycle as rice is very sensitive to water stress. Any attempts to reduce irrigation water results in yield reduction that threaten food security. 
Farmers generally follow the conventional method of transplanting as a way of crop establishment technique for rice in order to get the assured yield. Rice requires more amounts of water inputs as compared to other cereal crops. Maximum extent of the world's rice is produced under the conventional irrigation practice of continuous flooding. The growth and yield of transplanted rice are increased under continuous ponding as reported earlier by Marimuthu et al. (2010). But with continuous ponding, there is greater chance of high surface runoff, seepage and percolation. It is resulted in much lower WUE of rice than other crops. The WUE of rice will be improved by applying only the precise amount of water needed for the consumptive use. The beneficial effect of saturation in improving the grain yield of rice is being reported by Sudhakara et al. (2017). It is a challenging task to obtain optimum yield with less amount of water to meet food, social, economic and water security. To achieve this situation, the technique lies with increase in yield per unit transpiration, reducing the various irrigation losses, use of effective rainfall and application of irrigation water based on visible observation after disappearance of saturation. In this concept, irrigation water is applied to bring the saturation and afterwards, irrigation is provided after development of hair crack in the field. Several water management scientists revealed the maximization of WUE through application of deficit irrigation (Chowdhury et al. 2014; Reddy and Bandopadhyay, 2015; Kumar et al. 2015 and Diproshan et al. 2015).

Date of transplanting has profound influence on the performance of photo insensitive rice varieties. Date of transplanting plays a major role in influencing the growth, yield attributes, yield and grain quality of rice. Even though slight change to normal transplanting date leads to change the duration, growth and yield due to impact of environmental factors like air temperature and solar radiation. The growth parameters viz. plant height, tillers/ clump, leaf area index (LAI), dry matter production and crop growth rate were significantly reflected by early date of transplanting compared to late transplanted crop (Bagul, 2012; Nila et al. 2018; AlAmin et al. 2019 and Roy et al. 2019). The optimum date of transplanting varies from one region to another regiondue to variation in climate, soil and the appropriate irrigation management practices. With keeping these facts in view, the present field experiment was undertaken to find out the appropriate irrigation regimes and the optimum date of transplanting for summer rice for South Odisha.

\section{MATERIAL AND METHODS}

The field experiment was conducted during summer season in 2018-19 at Agriculture Research Farm, Bagusala of M.S. Swaminathan School of Agriculture, Centurion University of Technology and Management, Paralakhemundi, Odisha situated at $23^{\circ} \mathrm{N}$ latitude and $87^{\circ} \mathrm{E}$ longitude with an altitude of $182.9 \mathrm{~m}$ above the mean sea level. The soil of the experimental plot was sandy clay loam in texture, slightly acidic in reaction with $\mathrm{pH}$ of 6.4 , low in available nitrogen $(208 \mathrm{~kg} / \mathrm{ha})$ and high in available phosphorous (139 kg/ha) and potassium (390 kg/ ha). During cropping season, the amount of rain fall received during January, February, March, April was 28.0, 34.4, 33.0 and $29.4 \mathrm{~mm}$, respectively. The experiment was laid out in split plot design with three replications allocating irrigation treatments in main plot and dates of transplanting in subplots. The three main plot treatments were $\mathrm{I}_{1}$ (continuous ponding with $5 \pm 2 \mathrm{~cm}$ depth), $\mathrm{I}_{2}$ (continuous soil saturation with $3 \mathrm{~cm}$ depth) and $\mathrm{I}_{3}$ (saturation after hair crack with $3 \mathrm{~cm}$ depth) and four sub plot treatments were $\mathrm{D}_{1}$ (Transplanting on $23^{\text {rd }}$ January), $\mathrm{D}_{2}$ (Transplanting on $31^{\text {st }}$ January), $\mathrm{D}_{3}$ (Transplanting on $6^{\text {th }}$ February) and $\mathrm{D}_{4}$ (Transplanting on $13^{\text {th }}$ February). Rice variety MTU 1010 (Cotton Dora Sannalu) was transplanted with 33 days old seedlings at the spacing of $20 \mathrm{~cm}$ row to row and $15 \mathrm{~cm}$ plant to plant at different dates as mentioned in treatments. The well decomposed farm yard manure @ $5 \mathrm{t} /$ ha was applied just before final land preparation. The recommended fertilizer dose of 120:60:60 kg N: $\mathrm{P}_{2} \mathrm{O}_{5}: \mathrm{K}_{2} \mathrm{O}$ ha ${ }^{-1}$. At basal, $50 \% \mathrm{~N}$ and total $\mathrm{P}_{2} \mathrm{O}_{5}$ and $\mathrm{K}_{2} \mathrm{O}$ were applied and incorporated in soil before transplanting. Remaining $50 \% \mathrm{~N}$ was applied as top dressing during tillering and panicle initiation stage in equal splits. Growth parameters like plant height, number of tillers/clump, leaf area index, dry matter accumulation and crop growth were recorded at 30 and 60 DAT and harvest. Crop was harvested at full maturity stage. Both grain and straw yield were recorded at harvest after perfect 
sun drying. The water use efficiency (WUE) was calculated with standard formula. Finally collected data were statistically analysed as per procedures suggested by Gomez and Gomez (1984).

\section{RESULTS AND DISCUSSION}

Data pertaining to growth parameters like plant height, number of tillers/clump and leaf area index were presented in Table 1 . The data in Table 2 were mentioned for the dry matter accumulation, crop growth rate, grain and straw yield and water use efficiency under different irrigation regimes and dates of transplanting.

\section{Plant height}

\section{Effect of irrigation}

The significant difference was existed during 60 DAT and at harvest with different irrigation regimes regarding plant height but no significant difference was observed between irrigation treatments during 30 DAT. Maximum plant height was noticed in continuous ponding $(43.37 \mathrm{~cm}, 82.99 \mathrm{~cm}$ and 84.03 $\mathrm{cm})$ followed by saturation $(42.70 \mathrm{~cm}, 78.03 \mathrm{~cm}$ and $78.65 \mathrm{~cm}$ ) whereas minimum plant height was observed in saturation after hair crack $(40.63 \mathrm{~cm}$, $72.43 \mathrm{~cm}$ and $75.31 \mathrm{~cm}$ ) at 30 DAT, 60 DAT and at harvest, respectively. The continuous and sufficient availability of moisture under continuous ponding stimulate the cell division causing stem elongation that resulted in increased plant height. Similar favourable effect of irrigation was earlier reported by Rama Krishna et al. (2007) and Rahaman and Sinha (2013).

\section{Effect of date of transplanting}

At 30 DAT, the highest plant height was observed when transplanted on $31^{\text {st }}$ January $(44.22 \mathrm{~cm})$ which was at par with $6^{\text {th }}$ February $(43.29 \mathrm{~cm})$ but found superior over $13^{\text {th }}$ February $(41.02 \mathrm{~cm})$ and $23^{\text {rd }}$ January $(40.39 \mathrm{~cm})$. At 60 DAT, the tallest plant was recorded in transplanted date of $31^{\text {st }}$ January $(81.69 \mathrm{~cm})$ followed by $23^{\text {rd }}$ January $(79.32 \mathrm{~cm}), 6^{\text {th }}$ February $(77.13 \mathrm{~cm})$ where minimum plant height was observed at 13 February $(73.12 \mathrm{~cm})$. Plant height at harvest was in similar trend as that of 60 DAT recording $82.51 \mathrm{~cm}, 80.66 \mathrm{~cm}, 78.20 \mathrm{~cm}$ and 75.94 $\mathrm{cm}$ during $31^{\text {st }}$ January, $23^{\text {rd }}$ January, $6^{\text {th }}$ February and $13^{\text {th }}$ February, respectively. Shoot elongation continued to increase with the advancement of crop age and a rapid increase in plant height was noticed during earlier period of crop growth up to 60 DAT. Subsequent elongations was slower and thereafter, it decreased slowly up to maturity. Similar result in

Table 1: Effect of irrigation regimes and dates of transplanting on plant height, tillers/clump and leaf area index (LAI) of summer rice at different date after transplanting

\begin{tabular}{|c|c|c|c|c|c|c|c|c|c|}
\hline \multirow{2}{*}{ Treatment } & \multicolumn{3}{|c|}{ Plant height $(\mathrm{cm})$} & \multicolumn{3}{|c|}{ Tillers/clump } & \multicolumn{3}{|l|}{ LAI } \\
\hline & 30 DAT & 60 DAT & Harvest & 30 DAT & $60 \mathrm{DAT}$ & Harvest & 30 DAT & 60 DAT & Harvest \\
\hline \multicolumn{10}{|c|}{ Irrigation regimes } \\
\hline $\mathrm{I}_{1}$ & 43.37 & 82.99 & 84.03 & 11.39 & 14.03 & 11.63 & 1.95 & 5.37 & 2.81 \\
\hline $\mathrm{I}_{2}$ & 42.70 & 78.03 & 78.65 & 11.67 & 14.61 & 12.72 & 1.86 & 5.38 & 2.86 \\
\hline $\mathrm{I}_{3}$ & 40.63 & 72.43 & 75.31 & 11.36 & 13.36 & 11.32 & 1.88 & 5.36 & 2.74 \\
\hline $\operatorname{SEm}( \pm)$ & 1.15 & 0.34 & 0.92 & 0.21 & 0.38 & 0.13 & 0.03 & 0.03 & 0.03 \\
\hline $\mathrm{CD}$ & NS & 1.35 & 3.62 & NS & NS & 0.52 & NS & NS & NS \\
\hline \multicolumn{10}{|c|}{ Date of transplanting } \\
\hline $\mathrm{D}_{1}$ & 40.39 & 79.32 & 80.66 & 11.00 & 14.15 & 12.51 & 1.97 & 5.55 & 2.96 \\
\hline $\mathrm{D}_{2}$ & 44.22 & 81.69 & 82.51 & 12.11 & 14.78 & 12.42 & 1.90 & 5.49 & 2.84 \\
\hline $\mathrm{D}_{3}$ & 43.29 & 77.13 & 78.20 & 11.63 & 13.81 & 11.62 & 1.88 & 5.29 & 2.76 \\
\hline $\mathrm{D}_{4}$ & 41.02 & 73.12 & 75.94 & 11.15 & 13.26 & 11.00 & 1.84 & 5.16 & 2.66 \\
\hline $\operatorname{SEm}( \pm)$ & 0.99 & 0.59 & 0.41 & 0.27 & 0.23 & 0.14 & 0.03 & 0.03 & 0.03 \\
\hline $\mathrm{CD}$ & 2.94 & 1.75 & 1.23 & 0.80 & 0.67 & 0.43 & 0.08 & 0.10 & 0.07 \\
\hline
\end{tabular}

$I_{1}=$ continuous ponding with $5 \pm 2 \mathrm{~cm}$ depth; $I_{2}=$ continuous soil saturation with $3 \mathrm{~cm}$ depth; $I_{3}=$ saturation after hair crack with $3 \mathrm{~cm}$ depth; $D_{1}=$ Transplanting on $23^{\text {rd }}$ January; $D_{2}=$ Transplanting on $31^{\text {st }}$ January; $D_{3}=$ Transplanting on $6^{\text {th }}$ February and $D_{4}=$ Transplanting on $13^{\text {th }}$ February. 
Table 2: Dry matter accumulation, crop growth rate (CGR), grain and straw yield and water use efficiency (WUE) as influenced by irrigation regimes and dates of transplanting in summer rice

\begin{tabular}{|c|c|c|c|c|c|c|c|c|c|}
\hline \multirow[b]{2}{*}{ Treatment } & \multicolumn{3}{|c|}{ Dry matter $\left(\mathrm{g} / \mathrm{m}^{2}\right)$} & \multicolumn{3}{|c|}{ CGR (g/m²/day) } & \multirow{2}{*}{$\begin{array}{l}\text { Grain } \\
\text { yield } \\
\text { (t/ha) }\end{array}$} & \multirow{2}{*}{$\begin{array}{l}\text { Straw } \\
\text { yield } \\
(\mathrm{t} / \mathrm{ha})\end{array}$} & \multirow{2}{*}{$\begin{array}{l}\text { WUE } \\
(\mathrm{kg} / \mathrm{ha} / \mathrm{cm})\end{array}$} \\
\hline & 30 DAT & 60 DAT & Harvest & 0-30 DAT & $\begin{array}{l}30-60 \\
\text { DAT }\end{array}$ & $\begin{array}{l}60 \text { DAT- } \\
\text { Harvest }\end{array}$ & & & \\
\hline \multicolumn{10}{|c|}{ Irrigation regimes } \\
\hline $\mathrm{I}_{1}$ & 210.60 & 983.92 & 1201.75 & 6.90 & 25.78 & 7.47 & 4.57 & 7.58 & 37.01 \\
\hline $\mathrm{I}_{2}$ & 208.23 & 981.88 & 1192.08 & 6.82 & 25.79 & 7.52 & 4.30 & 7.62 & 39.39 \\
\hline $\mathrm{I}_{3}$ & 210.21 & 974.88 & 1089.08 & 6.88 & 25.49 & 4.12 & 3.38 & 7.51 & 49.62 \\
\hline SEm $( \pm)$ & 0.58 & 3.21 & 11.43 & 0.02 & 0.10 & 0.44 & 0.09 & 0.06 & 1.07 \\
\hline CD & NS & NS & 44.88 & NS & NS & 1.74 & 0.35 & NS & 4.22 \\
\hline \multicolumn{10}{|c|}{ Date of transplanting } \\
\hline $\mathrm{D}_{1}$ & 212.52 & 983.00 & 1217.89 & 6.96 & 25.68 & 7.26 & 4.72 & 7.63 & 47.09 \\
\hline $\mathrm{D}_{2}$ & 215.56 & 1005.72 & 1248.67 & 7.06 & 26.34 & 8.26 & 4.50 & 7.99 & 44.50 \\
\hline $\mathrm{D}_{3}$ & 206.54 & 975.72 & 1123.33 & 6.76 & 25.64 & 5.73 & 3.78 & 7.46 & 39.37 \\
\hline $\mathrm{D}_{4}$ & 204.08 & 956.44 & 1054.00 & 6.68 & 25.08 & 4.24 & 3.34 & 7.20 & 37.09 \\
\hline SEm $( \pm)$ & 0.66 & 3.49 & 10.02 & 0.02 & 0.11 & 0.41 & 0.07 & 0.13 & 0.81 \\
\hline $\mathrm{CD}$ & 1.96 & 10.37 & 29.78 & 0.07 & 0.33 & 1.21 & 0.21 & 0.38 & 2.42 \\
\hline
\end{tabular}

$I_{1}=$ continuous ponding with $5 \pm 2 \mathrm{~cm}$ depth; $I_{2}=$ continuous soil saturation with $3 \mathrm{~cm}$ depth; $I_{3}=$ saturation after hair crack with $3 \mathrm{~cm}$ depth; $D_{1}=$ Transplanting on $23^{\text {rd }}$ January; $D_{2}=$ Transplanting on $31^{\text {st }}$ January; $D_{3}=$ Transplanting on $6^{\text {th }}$ February and $D_{4}=$ Transplanting on $13^{\text {th }}$ February.

increase of plant height with transplanting on $31^{\text {st }}$ January was reported by Roy et al. (2019).

\section{Tillers/clump}

\section{Effect of irrigation}

Irrigation treatments failed to exhibit the significant effect on number of tillers/clump during 30 DAT and 60 DAT. Rather it had positive impact at harvest. The maximum tillers/clump was noticed in saturation condition $(11.67,14.61$ and 12.72$)$ followed by continuous ponding (11.39, 14.03 and 11.63) while minimum tillers/clump was in saturation after hair crack (11.36, 13.36 and 11.32) during 30 DAT, 60 DAT and harvest, respectively. At saturation level, the depth of the water is less and continuous maintenance of it provides better aeration and uptake of nutrients thereby facilitating the production of more tillers.

\section{Effect of date of transplanting}

The tillers/clump was significantly influenced by different dates of transplanting throughout the growth stages. The highest tillers/clump was noticed in transplanting date of 31st January (12.11 and 14.78) during 30 and $60 \mathrm{DAT}$, respectively. It remained at par with $6^{\text {th }}$ February $(11.63)$ and $23^{\text {rd }}$
January (14.15) during 30 and 60 DAT, respectively. At harvest, $23^{\text {rd }}$ January (12.51) produced more tillers/clump which was at par with $31^{\text {st }}$ January (12.42). The lowest tillers/clump was observed in $13^{\text {th }}$ February with the values of 11.15, 13.26 and 11.00 during 30 and 60 DAT and at harvest, respectively. These results are in conformity with the findings of Al-amin et al. (2019) who reported that number of total tillers/clump was drastically reduced when transplanted in late due to temperature variation.

\section{Leaf area index}

\section{Effect of irrigation}

At 30 DAT, 60 DAT and harvest, there was no significant difference among the irrigation regimes. Maximum LAI was noticed in continues ponding (1.95) followed by saturation after hair crack (1.88) and minimum LAI with saturation (1.86) during 30 DAT. At 60 DAT, LAI at saturation (5.38) was the highest closely followed by continues ponding (5.37) and the lowest LAI being noticed in saturation after hair crack (5.36). During harvest, the LAI behaved the exact trend as observed at 60 DAT. This was possible due to adequate moisture supply which influenced the growth of leaves and production of more number of larger sized leaves. Thus, it 
increased in number of green leaves and number of shoots per-unit area resulted in better nutrition under saturation water regime consequently reflected the LAI. It was also observed that LAI increased up to 60 DAT thereafter, it decreased due to aging, senescence, mortality and leaf drying. It is in agreement with the findings of Kumar et al. (2015).

\section{Effect of date of transplanting}

Maximum LAI was noticed in transplanting date of $23^{\text {rd }}$ January $(1.97)$ which was at par with $31^{\text {st }}$ January (1.90) at 30 DAT. It was followed by $6^{\text {th }}$ February (1.88) and minimum LAI on $13^{\text {th }}$ February (1.84). During 60 DAT, the highest LAI was recorded in $23^{\text {rd }}$ January (5.55) which remained at par with $31^{\text {st }}$ January (5.49) but were significantly superior over $6^{\text {th }}$ February (5.29) and $13^{\text {th }}$ February (5.16). The LAI at harvest followed the similar trend as that of 60 DAT. Throughout the growth stages, the lowest LAI was noticed with delayed transplanted date on $13^{\text {th }}$ February.

\section{Dry matter Production}

\section{Effect of irrigation}

During harvest, dry matter production was remarkably influenced by irrigation treatments. At all the growth stages, the dry matter accumulation was increased in continuous ponding over saturation and saturation after hair crack. The continuous ponding with irrigation depth of $5 \pm 2 \mathrm{~cm}$ produced the maximum dry matter of 210.60 and $983.92 \mathrm{~g} / \mathrm{m}^{2}$ at 30 and 60 DAT, respectively. At harvesting stage, dry matter production in continuous ponding (1201.75 $\mathrm{g} / \mathrm{m}^{2}$ ) was statistically at par with saturation (1192.08 $\mathrm{g} / \mathrm{m}^{2}$ ) and minimum dry matter accumulated in saturation after hair crack $\left(1089.08 \mathrm{~g} / \mathrm{m}^{2}\right)$. Increased growth under continuous submergence is due to effective uptake of water and nutrients under sufficient moisture condition resulting in increase in plant height, tiller number and dry matter accumulation. The results are in conformity with the findings of Maheswari et al. (2000) and Marimuthu et al. (2010).

\section{Effect of date of transplanting}

Significantly the highest dry matter production was recorded in $31^{\text {st }}$ January at $30 \mathrm{DAT}, 60 \mathrm{DAT}$ and harvest $\left(215.56 \mathrm{~g} / \mathrm{m}^{2}, 1005.72 \mathrm{~g} / \mathrm{m}^{2}\right.$ and $1248.67 \mathrm{~g} /$ $\mathrm{m}^{2}$, respectively). It was followed by $23^{\text {rd }}$ January producing the dry matter of $212.52 \mathrm{~g} / \mathrm{m}^{2}, 983.00$ $\mathrm{g} / \mathrm{m}^{2}$ and $1217.89 \mathrm{~g} / \mathrm{m}^{2}$ at $30 \mathrm{DAT}, 60 \mathrm{DAT}$ and harvest, respectively. Rice transplanted on $13^{\text {th }}$ February gave the lowest dry matter of $204.08 \mathrm{~g} / \mathrm{m}^{2}$, $956.44 \mathrm{~g} / \mathrm{m}^{2}$ and $1054 \mathrm{~g} / \mathrm{m}^{2}$ at $30 \mathrm{DAT}, 60 \mathrm{DAT}$ and harvest, respectively. Increase in plant height, tillers/ clump and LAI resulted in better interception of sunlight and efficient photosynthesis thus provided favourable condition for enhancement of dry matter production during transplanting of rice in end of January.

\section{Crop growth rate}

\section{Effect of irrigation}

Crop growth rate is a complex interaction between the plant growth and its environment. The CGR was non-significant in irrigation treatments during 0-30 DAT and 30-60 DAT. But CGR between 60 DAT to harvest was significantly different among irrigation treatments. Maximum CGR was noticed in continuous ponding $\left(6.90 \mathrm{~g} / \mathrm{m}^{2} /\right.$ day $)$ followed by saturation after hair crack $\left(6.88 \mathrm{~g} / \mathrm{m}^{2} /\right.$ day $)$ and minimum CGR found in saturation condition $(6.82$ $\mathrm{g} / \mathrm{m}^{2} /$ day) during 0-30 DAT. At 30-60 DAT, the highest CGR was obtained in saturation (25.79 g/ $\mathrm{m}^{2} /$ day) closely followed by continuous ponding $\left(25.78 \mathrm{~g} / \mathrm{m}^{2} /\right.$ day $)$ and the lowest was in saturation after hair crack $\left(25.49 \mathrm{~g} / \mathrm{m}^{2} /\right.$ day $)$. The CGR during 60 DAT-harvest was significantly reflected with irrigation treatments in which maximum CGR was found with saturation $\left(7.52 \mathrm{~g} / \mathrm{m}^{2} /\right.$ day $)$. It was at par with continuous ponding $\left(7.47 \mathrm{~g} / \mathrm{m}^{2} /\right.$ day $)$ and minimum CGR was noticed in saturation after hair crack $\left(4.12 \mathrm{~g} / \mathrm{m}^{2} /\right.$ day $)$. These experimental results are in close conformity with the findings of Kumar et al. (2015).

\section{Effect of date of transplanting}

Significant variation in CGR was found on all four dates of transplanting. During 0-30 DAT, the CGR was significantly the highest with $31^{\text {st }}$ January $(7.06$ $\mathrm{g} / \mathrm{m}^{2} /$ day). It was followed by $23^{\text {st }}$ January $(6.96$ $\mathrm{g} / \mathrm{m}^{2} /$ day $), 6^{\text {th }}$ February $\left(6.76 \mathrm{~g} / \mathrm{m}^{2} /\right.$ day $)$ and $13^{\text {th }}$ February $\left(6.68 \mathrm{~g} / \mathrm{m}^{2} /\right.$ day $)$ which were significantly different from each other. Significant increase in CGR between $30-60$ DAT was recorded in $31^{\text {st }}$ 
January $\left(26.34 \mathrm{~g} / \mathrm{m}^{2} /\right.$ day). It was followed by $23^{\text {rd }}$ January $\left(25.68 \mathrm{~g} / \mathrm{m}^{2} /\right.$ day $)$ being at par with the $6^{\text {th }}$ February (25.08 g/m²/day). Between 60 DAT-harvest, transplanting on $31^{\text {st }}$ January recorded maximum CGR $\left(8.26 \mathrm{~g} / \mathrm{m}^{2} /\right.$ day $)$ which was statistically similar with $23^{\text {rd }}$ January $\left(7.26 \mathrm{~g} / \mathrm{m}^{2} /\right.$ day). It was followed by $6^{\text {th }}$ February $\left(5.73 \mathrm{~g} / \mathrm{m}^{2} /\right.$ day) and $13^{\text {th }}$ February $(4.24$ $\mathrm{g} / \mathrm{m}^{2} /$ day) which were found significantly different. The increase in CGR in $31^{\text {st }}$ January was possible due to favourable environmental conditions such as temperature and relative humidity during its different phenophases compared to late planting. The enhancement of CGR in early transplanting crop has also been reported earlier by Yeasmin et al. (2008).

\section{Grain yield}

\section{Effect of irrigation}

The continuous ponding produced the highest grain yield (4.57 t/ha) which was at par with saturation (4.30 t/ha). They were found superior over saturation after hair crack (3.38 t/ha). Moisture stress condition for a long period causes reduced entry of $\mathrm{CO}_{2}$ resulted in partial stomatal closing due to excessive evapotranspiration. Thus, scarcity of $\mathrm{CO}_{2}$ and water ultimately hampers the process of photosynthesis resulting in poor translocation and accumulation of photosynthates which finally reduced crop yield. This result corroborates the findings of Chowdhury et al. (2012) and Rahman et al. (2014).

\section{Effect of dates of transplanting}

The highest grain yield was recorded when transplanted on $23^{\text {rd }}$ January (4.72 $\mathrm{t} / \mathrm{ha}$ ) followed by $31^{\text {st }}$ January $(4.50 \mathrm{t} / \mathrm{ha})$ transplanting. The reduction in grain yield was observed with delayed transplanting of $6^{\text {th }}$ February $3.78 \mathrm{t} / \mathrm{ha}$ ) and $13^{\text {th }}$ February (3.34 t/ha). Increase in number of tillers and LAI under earlier dates of transplanting resulted in better interception of sun light that enhanced the photosynthesis and dry matter production thus, favoured the translocation of photosynthates from source to sink there by augmented the grain yield. This result is in line with findings of Roy et al. (2019).

\section{Straw yield}

\section{Effect of irrigation}

It was evident from data that different water regimes had no positive effect on straw yield. The maximum straw yield was produced in saturation (7.62 t/ha) followed by continuous ponding (7.58 t/ha) and saturation after hair crack (7.51 t/ha). It happens so due to increase in plant height and number of tillers/ clump which resulted in improvement of biomass production that ultimately reflected the straw yield.

\section{Effect of date of transplanting}

The transplanting of rice on $31^{\text {st }}$ January produced the maximum straw yield $(7.99 \mathrm{t} / \mathrm{ha})$ that remained at par with $23^{\text {rd }}$ January $(7.63 \mathrm{t} / \mathrm{ha})$. The lowest

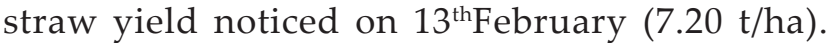
It is ascribed to longer vegetative phase and conducive climatic conditions that exhibited the favourable effect in increasing the dry matter production leading to augmentation of straw yield. The results are in agreement with the findings of Assaduzzaman (2006).

\section{Water use efficiency (WUE)}

\section{Effect of irrigation}

Significant increase in WUE was recorded in saturation after hair crack $(49.62 \mathrm{~kg} / \mathrm{ha} / \mathrm{cm})$ over all the irrigation treatments. The next best result was obtained in saturation $(39.3 \mathrm{~kg} / \mathrm{ha} / \mathrm{cm})$ which remained at par with continuous ponding (37.0 $\mathrm{kg} / \mathrm{ha} / \mathrm{cm}$ ). The WUE decreased with increase of irrigation frequency. Similar result was depicted by Kumar et al. (2015).

\section{Effect of date of transplanting}

The maximum WUE was noticed in $23^{\text {rd }}$ January $(47.09 \mathrm{~kg} / \mathrm{ha} / \mathrm{cm})$ that differed significantly from all other transplanting dates. The WUE was gradually reduced with delayed transplanting dates of $31^{\text {st }}$ January $(44.50 \mathrm{~kg} / \mathrm{ha} / \mathrm{cm}), 6^{\text {th }}$ February $(39.37 \mathrm{~kg} / \mathrm{ha} /$ $\mathrm{cm})$ and $13^{\text {th }}$ February $(37.09 \mathrm{~kg} / \mathrm{ha} / \mathrm{cm})$. The WUE in transplanting date of $31^{\text {st }}$ January was significantly higher than $6^{\text {th }}$ February and $13^{\text {th }}$ February and no significant variation was found between last two dates. Rainfall received during the crop development stages in early dates of transplanting curtailed the irrigation requirement that caused the enhancement of WUE. 


\section{CONCLUSION}

The irrigation regime of continuous ponding with the depth of $5 \pm 2 \mathrm{~cm}$ and continuous saturation with the depth of $3 \mathrm{~cm}$ during summer season resulted in enhancement of crop growth parameters in terms of plant height, number of tillers/clump, crop growth rate, leaf area index and dry matter production there by reflecting the yield in transplanted rice. The WUE was positively increased under reduced irrigation of saturation after hair crack with $3 \mathrm{~cm}$ depth. Transplanting of rice on $23^{\text {rd }}$ January improved all crop growth parameters and produced the highest grain yield and WUE.

\section{REFERENCES}

Al-Amin, M., Nasrin, S., Mabud, G.M.K.A, Sani, H.N.Md. 2019. Effect of planting date on the performance of high yield potential varieties of rice in Bangladesh. Asian Journal of Advances in Agricultural Research, 9: 1-11.

Assaduzzaman, M. 2006. Effect of spacing and date of transplanting on the performance of bororice cvb. BRRI dhan b 29. M Sc Thesis, Department of Agronomy, Bangladesh Agricultural University, Mymensingh.

Bagul, V.B. 2012. Influence of sowing and transplanting dates on physiological parameters of different summer rice varieties. M Sc Thesis, Department of crop physiology, Navsari Agricultural University, Gujarat.

Chowdhuary, M.R, Kumar, V., Sattar, A. and Brahmachari, K. 2014. Studies on the water use efficiency and nutrient uptake by rice under System of intensification. The Bioscan, 9: 85-88.

Chowdhury, R.M., Kumar, V. and Brahmachari, K. 2012. Effect of different water and nutrient management practices on rice grown under SRI. Journal of Crop and Weed, 8: 36-39.

Diproshan, Dewangan, M., Khajanji, S.N., Rajendra, L., and Kumar, M.R. 2015. Effect of irrigation regimes and nitrogen levels on productivity and water use efficiency of rice (Oryza sativa L.) under SRI cultivation. The Ecoscan, 7: 147-151.

Directorate of Economics and Statistics. 2018. Agricultural stastistics at a glance, Ministry of Agriculture and Farmers Welfare Government of India.

Gomez, K.A. and Gomez, A.A. 1984. Statistical procedures for Agricultural Research. Second Edition (IRRI John Wiley \& Sons Publication: New York).

Kumar, R., Das, S., Kumar, V., Dwivedi, K.D. and Das, L. 2015. Studies on irrigation and weed management for enhancing rice yield and water productivity under system of rice intensification. The Bioscan, 10(1): 417-420.
Maheswari, J., Bose, J., Sangeetha, S.P., Sanjutha, S. and Priya, R.S. 2008. Irrigation regimes and $\mathrm{N}$ levels influence on chlorophyll, leaf area index, proline and soluble protein content of aerobic rice (Oryza sativa L.). International Journal of Agriculture Research, 3: 307-316.

Marimuthu, S., Subulakshmi, S. and Subbin, P. 2010. Effect of irrigation regimes on water saving, growth and yield of rice under low land condition. Crop Research, 39: 9-13.

Nila, N.Y., Paul, S.K. and Sarkar, M.A.R. 2018. Growth, yield and grain protein content of aromatic bororice (cv. BRRI dhan50) as influenced by date of transplanting and nutrient management. Archives of Agriculture and Environmental Science, 3: 116-122.

Rahman, J.M., Biswas, K.P., Amin, R.M.K. and Zahan, A. 2014. Yield of boro rice under system of rice intensification with different water regimes and manural status. Bangladesh Agronomy Journal, 17: 1-8.

Rahman, S. and Sinha, A.C. 2013. Effect of water regimes and organic sources of nutrients for higher productivity and nitrogen use efficiency of summer rice (Oryza sativa L). African Journal of Agricultural Research, 8:6189-6195.

Ramakrishna, Y., Singh, S. and Parihar, S.S. 2007. Influence of irrigation regime and nitrogen management on productivity, nitrogen uptake and water use by rice (Oryza sativa). Indian Journal of Agronomy, 52: 102-106.

Reddy, S.G. and Bandyopadhyay, P. 2015. Effect of irrigation scheduling and weed management practices on performance of lowland transplanted rice. Journal Crop and Weed, 11: 118-123.

Roy, K.T., Paul, S.K. and Sarkar, R.A.Md. 2019. Influence of date of transplanting on the growth and yield performance of high yielding varieties of boro rice. Journal of Bangladesh Agricultural University, 17: 301-308.

Sarkar, M.A.R., Hossain, M.A. and Paul, S.K. 2017. Impact of row arrangements, age of tiller seedlings and number of tiller seed-lings hill $^{-1}$ on the growth performance of transplanted aman rice (cv. BR23). Archives of Agriculture and Environmental Science, 2: 152-161.

Sudhakara, T.M., Srinvas, A., Kumar, R.M., Prakash, R.T. and Kishor, M.J. 2017. Productivity of rice as influenced by irrigation regimes and nitrogen management practices under SRI. Annals of Plant and Soil Research, 19: 253-259.

Yeasmin, M.S., Rahman, M.M., Rahman, M.S., Ahmed, T. and Chowdhury, A.K.M.M.B. 2008. Effects of date of transplanting on the growth parameters of boro rice varieties under the system of rice intensification. Bangladesh Journal of Envronmental Science, 14: 71-75. 
